\title{
I mproving obstructive sleep apnea in a morbidly obese woman: Role of dietary modification and physical activity
}

\author{
Gilles Plourde', Christopher E. Kline ${ }^{2}$ \\ 1. Cliniques Médicales de Nutrition et D’Amaigrissement, Gatineau, Quebec, Canada. 2. Department of Psychiatry, \\ University of Pittsburgh School of Medicine, Pittsburgh PA, USA.
}

Correspondence: Gilles Plourde. Address: Cliniques Médicales de Nutrition et D'Amaigrissement. 4 Taschereau Street, Gatineau, Quebec, J8Y 2V5, Canada. Email: gilles.plourde@hc-sc.gc.ca

Received: January 9, $2013 \quad$ Accepted: March 21, 2013

Online Published: April 25, 2013

DOI : $10.5430 /$ cns.v1n3p1

URL: http://dx.doi.org/10.5430/cns.v1n3p1

\begin{abstract}
Introduction: With obstructive sleep apnea (OSA) present in over $50 \%$ of those who are morbidly obese and the well-documented effects of OSA on health and functioning, proper management of this condition is an important consideration among treatment providers. Weight loss is a common goal for patients, though bariatric surgery carries significant risk for those with OSA. As a means of achieving weight loss, lifestyle interventions have been shown to significantly reduce OSA severity with minimal side effects. However, whether these controlled studies can be effectively applied to clinical practice for treating OSA is unknown. We describe how an intensive lifestyle intervention was successfully employed for the treatment of severe OSA in clinical practice.
\end{abstract}

Case presentation: The patient, a 27 year old morbidly obese Caucasian woman (body mass index [BMI] $=56.2 \mathrm{~kg} / \mathrm{m}^{2}$, neck circumference $=42 \mathrm{~cm}$ ), presented with severe OSA (apnea-hypopnea index $=42$ ) to our obesity clinic after refusing bariatric surgery. She was treated with a very-low-calorie diet for 6 months followed by a low-calorie diet for another 10 months combined with a progressive moderate-intensity exercise program and close medical supervision by a multidisciplinary management team. With treatment, she was able to reduce her weight by $38 \%$ (current BMI $=34.6$ $\mathrm{kg} / \mathrm{m}^{2}$ ), decrease her neck circumference by $17 \%$ (currently $35 \mathrm{~cm}$ ), and discontinue OSA treatment with continuous positive airway pressure.

Conclusion: This case demonstrates that the use of dietary modification combined with physical activity may be a safe and effective option for improving OSA in obese patients. In particular, physical activity may be beneficial for the management of OSA for reasons beyond facilitating weight loss.

\section{Key words}

Obstructive sleep apnea, Lifestyle intervention, Very low calorie diet, Low calorie diet, Exercise

\section{I ntroduction}

Obstructive sleep apnea (OSA) is a prevalent sleep disorder, as approximately $15 \%-25 \%$ of adults have at least mild-severity OSA and 5\%-10\% have at least moderate-severity OSA ${ }^{[1,2]}$. Although approximately $25 \%$ of those with 
OSA have excessive sleepiness ${ }^{[1]}$, commonly assessed clinically the Epworth Sleepiness Scale ${ }^{[3]}$, the majority of afflicted patients do not exhibit daytime dysfunction ${ }^{[4]}$. Nevertheless, the health implications of OSA are potentially severe. Obstructive sleep apnea is increasingly recognized as an independent risk factor for cardiac, neurologic, and perioperative morbidities and, if left untreated, may lead to cognitive impairment, depression, cardiovascular disease, type 2 diabetes, and/or early mortality ${ }^{[5]}$. Unfortunately, OSA remains undiagnosed in a substantial portion of the population. It is imperative for all treatment providers to remain vigilant in identifying patients with signs and symptoms of OSA ${ }^{[4]}$. Obesity is the most important risk factor for OSA and in 58\% of adults with moderate to severe OSA excess weight is the primary attribute ${ }^{[6]}$. Moreover, the prevalence of OSA can be as high as $78 \%$ in morbidly obese patients who present for bariatric surgery ${ }^{[7]}$. Increased central obesity and fat deposition in the upper airway are believed to increase the likelihood of airway collapse in these patients ${ }^{[8]}$.

For morbidly obese patients with OSA, continuous positive airway pressure (CPAP) remains the gold standard treatment. Weight loss is also a primary goal, and bariatric surgery has been shown to be an effective means of achieving weight loss in this population ${ }^{[9]}$. However, these procedures are accompanied by significant health risk (e.g., surgical complications, adverse reaction to anesthesia) ${ }^{[10]}$, and up to one-third of patients opt to forgo this form of treatment ${ }^{[11]}$. In contrast, lifestyle interventions, which combine very-low calorie diets (VLCD) with increased physical activity, promote a behavioral method of weight loss. Lifestyle interventions have been shown to be safe and effective for patients with OSA $^{[12,13]}$, with beneficial outcomes maintained up to 1-year follow-up ${ }^{[14,15]}$. For instance, in a study of obese patients with mild to moderate OSA, treatment with a VLCD combined with aerobic and resistance exercise resulted in improvements in daytime sleepiness and quality of life as well as cardiometabolic outcomes ${ }^{[16]}$. However, it is unknown whether the interventions utilized in these rigorously controlled experimental studies can be applied to clinical practice for the treatment of OSA. The purpose of this report was to document the results of intensive lifestyle intervention on the OSA severity and health of a morbidly obese patient.

\section{Case presentation}

We report the case of a 27-year old obese Caucasian woman with severe OSA. She presented with disruptive snoring, sleep maintenance difficulty, restlessness, unrefreshing sleep and depressive symptoms, for which she was prescribed venlafaxine $25 \mathrm{mg} /$ day. She did not present with other comorbid conditions. Upon a physical exam, her weight was $153 \mathrm{~kg}$, her height was $165 \mathrm{~cm}$ (body mass index [BMI] $=56.2 \mathrm{~kg} / \mathrm{m}^{2}$ ), her neck circumference was $42 \mathrm{~cm}$, and her waist circumference was $141 \mathrm{~cm}$. She reported no physical activity in the past 6 months, was a non-smoker, and reported refraining from alcohol and illicit drugs. She had a normal blood pressure (128/78 mm Hg), normal menstrual cycles, and her cardiac and pulmonary exams were normal. She did not present with retrognathia, micrognathia, nasal or palate deformities or enlarged tonsils. An overnight polysomnographic (PSG) study was performed and confirmed her severe OSA. From the overnight PSG, the patient had an apnea-hypopnea index (AHI) of 42 (an AHI $\geqslant 30$ is indicative of severe OSA), with an oxygen saturation below $90 \%$ for $5.1 \%$ of the time she slept. However, her Epworth Sleepiness Scale score was normal, and other laboratory assessments (e.g., complete blood count, liver enzymes, lipid profile, and fasting glucose) were normal. She was then prescribed an autotitrating continuous positive airway pressure (CPAP) device, with nightly pressure to eliminate $95 \%$ of apneas averaging $15 \mathrm{~cm} \mathrm{H2O}$, and bariatric surgery was recommended. After the initial evaluation, the patient decided to decline the bariatric surgery.

Following surgery refusal, the patient was referred to our obesity clinic and was managed by a multidisciplinary team comprising a physician, nutritionist, exercise specialists and nurses. Because of her morbid obesity, severe OSA and family history of cardiac disorders, we decided to put this patient on a VLCD as previously used safely and efficiently for the treatment of OSA ${ }^{[12,13]}$ and in the long-term (i.e., > 12-month) treatment of severe obesity ${ }^{[17]}$. Furthermore, a review of randomized controlled trials has reported that VLCD with active follow-up treatment seems to be one of the better treatment modalities related to long-term weight-maintenance success ${ }^{[18]}$. Briefly, a VLCD provides $400-800 \mathrm{kcal} /$ day of high-quality protein (1.2 to $1.5 \mathrm{~g} / \mathrm{kg}$ of ideal body weight) and carbohydrate (approximately $50 \mathrm{~g} / \mathrm{day}$ ) fortified with the 
recommended daily allowance of vitamins, minerals and trace elements. The purpose of the VLCD is to achieve large weight loss while providing adequate nutrition and preserving vital lean body mass. The patient was advised to continue CPAP treatment each night, and under the supervision of an exercise specialist an exercise program was prescribed that gradually progressed to around $4 \mathrm{~km}$ of daily walking. Frequent follow-up examinations (i.e., every 1-2 weeks) were provided by members of the management team. During that period, the patient also received specific counseling on dietary and physical activity interventions as described by Plourde and Prud 'homme ${ }^{[19]}$. The reader is referred to this Continuous Medical Education article for recommendations on the counseling of obese patients. After 6 months of this treatment, the patient achieved a $25 \%$ weight loss (153 kg to $115 \mathrm{~kg}$ ). The patient reported excellent compliance to nightly CPAP use, and this was verified upon nightly usage data derived from the device (averaging $8.6 \mathrm{~h} / \mathrm{night}$ of use). In addition, excellent compliance to the exercise regimen was achieved. As a result of treatment, the patient experienced a $27 \%$ reduction in her nightly CPAP pressure ( $15 \mathrm{~cm} \mathrm{H}_{2} \mathrm{O}$ to $11 \mathrm{~cm} \mathrm{H}_{2} \mathrm{O}$ ), 5\% decrease in her neck circumference (42 cm to $40 \mathrm{~cm}$ ) and 3.5\% reduction in waist circumference $(141 \mathrm{~cm}$ to $136 \mathrm{~cm})$. Moreover, because the patient reported significant improvement in her mental health status, we decided to discontinue her venlafaxine use. The patient was then put on a low-calorie diet (LCD), consisting of $800-1000 \mathrm{kcal} /$ day (45\%-50\% protein, $25 \%-35 \%$ carbohydrates, $15 \%-20 \%$ fat) fortified with the recommended daily allowance of vitamins, minerals, and trace elements. The patient was advised to continue CPAP use during the LCD, continued to be followed on regular basis (i.e., every 1-2 weeks) by the management team and received dietary and physical activity counseling. Counseling on long-term maintenance of weight loss and prevention of weight regain was also initiated in preparation for the maintenance phase after her weight loss ${ }^{[19]}$. In addition, under the supervision of our exercise specialist, the patient decided to add 30 min of stationary biking and increase walking to approximately $5 \mathrm{~km} /$ day, equating to an approximately $50 \%$ increase in physical activity from the prior 6 months. After 10 months of a LCD combined with regular physical activity, the patient reported complete resolution of OSA symptoms including sleep maintenance difficulty, restlessness, unrefreshing sleep and depressive symptoms, and achieved a weight loss of $59 \mathrm{~kg}$ (38\% from baseline; $153 \mathrm{~kg}$ to $94 \mathrm{~kg}$ [BMI from $56.2 \mathrm{~kg} / \mathrm{m}^{2}$ to $34.6 \mathrm{~kg} / \mathrm{m}^{2}$ ]) with a $17 \%$ reduction in neck circumference $(42 \mathrm{~cm}$ to $35 \mathrm{~cm})$ and $7 \%$ reduction in waist circumference $(141 \mathrm{~cm}$ to $131.5 \mathrm{~cm})$. Because the patient was completely asymptomatic of OSA confirmed by the medical assessment (i.e., her initial symptoms of disruptive snoring and sleep complaints were no longer present), she discontinued CPAP use. Although a second PSG study may have helped to objectively quantify her reduction in OSA severity, the patient refused to be reassessed due to the inconvenience of the first overnight PSG experience. Although no longer being treated for OSA, the patient continues to lose weight and maintains a high motivation for additional weight loss. The objective of this patient and clinical team is to continue treatment in order to reduce her weight below the BMI 'obesity' classification (i.e., $<30.0 \mathrm{~kg} / \mathrm{m}^{2}$ ), which would entail approximately $13 \mathrm{~kg}$ of additional weight loss.

\section{Discussion}

This case report demonstrates the potential utility of intensive lifestyle intervention, provided by a multidisciplinary team, for the treatment of OSA in morbidly obese adults, and suggests that the procedures utilized in experimental trials may have similar effectiveness in clinical practice for treating OSA. This is especially important due to the higher health risks of bariatric surgery for patients with OSA (e.g., severe oxygen desaturation, cardiac arrhythmias, and postoperative infections) ${ }^{[20,21]}$. As with our patient, in a recent study of 159 patients with a mean BMI of $47.2 \mathrm{~kg} / \mathrm{m}^{2}, 32 \%$ preferred lifestyle treatment to bariatric surgery due to the fear of general anesthesia and surgery ${ }^{[11,22]}$. Although bariatric surgery leads to a greater weight loss at 1 year, intensive lifestyle interventions similar to that employed here lead to clinically significant weight loss and similar improvements in risk factors and resolution of comorbidities in patients with morbid obesity ${ }^{[23]}$. Randomized controlled trials strongly suggest that weight reduction from a healthy diet and increased physical activity may correct or at least improve symptoms in patients with mild OSA and in OSA patients with diabetes ${ }^{[12,24]}$. Moreover, it has recently been demonstrated that the initial improvements in OSA after treatment with a VLCD ${ }^{[13]}$ can be maintained after one year in obese men with moderate to severe OSA, with adults who lose the most weight or have the most severe OSA at baseline benefitting the most from the VLCD ${ }^{[15]}$. Therefore, evidence suggests that weight loss via lifestyle intervention can be an acceptable alternative to bariatric surgery in obese patients with OSA.

Published by Sciedu Press 
As a means of achieving weight loss, increasing physical activity has been commonly recommended for the management of OSA. However, there is emerging evidence that physical activity may reduce OSA severity independent of its modest effects upon weight loss ${ }^{[25]}$. Epidemiologic research has demonstrated that adults who are physically active have a reduced risk of OSA compared to adults who are less active ${ }^{[26]}$. Moreover, experimental studies have found the AHI to be reduced up to $50 \%$ following exercise training despite minimal or no weight loss ${ }^{[27-29]}$. Exercise may reduce OSA by strengthening and increasing the fatigue resistance of upper airway dilator muscles and/or attenuating respiratory instability due to sleep fragmentation; however, these hypotheses need to be examined empirically.

The benefits of exercise for adults with OSA also may extend to daytime function. Following the lifestyle intervention, our patient was able to discontinue antidepressant medication use. Previous research has shown that exercise training results in decreased fatigue, sleepiness, and depressive symptoms, along with improvements in vigor and selected aspects of quality of life ${ }^{[16,27,30]}$ in adults with OSA. Moreover, CPAP use supplemented with 2 months of exercise training results in greater reductions in sleepiness and improvements in aspects of quality of life and mood state compared to CPAP alone ${ }^{\text {[31] }}$. Therefore, in addition to reducing OSA symptoms, evidence suggests that regular physical activity can have a positive impact on daytime function and quality of life in obese patients.

In conclusion, this case report demonstrates that the use of a VLCD followed by a LCD combined with regular physical activity and counseling delivered by a multidisciplinary team is safe and effective at improving OSA symptoms in morbidly obese patients. In particular, incorporating physical activity into treatment may be especially beneficial for the management of OSA. Greater consideration should be made toward integrating intensive lifestyle interventions into clinical practice for the treatment of OSA.

\section{Acknowledgments}

The authors wish to acknowledge Dr. Henri P. Tuomilehto from Kuopio University Hospital, Kuopio, Finland, for his scientific advice and documentation.

\section{Conflicting interest}

The authors declared no conflict of interest.

\section{References}

[1] Durán J, Esnaola S, Rubio R, Iztueta A. Obstructive sleep apnea-hypopnea and related clinical features in a population-based sample of subjects aged 30 to 70 yr. Am J Respir Crit Care Med. 2001;163:685-689. PMid:11254524

[2] Tishler PV, Larkin EK, Schluchter MD, Redline S. Incidence of sleep-disordered breathing in an urban adult population: the relative importance of risk factors in the development of sleep-disordered breathing. JAMA. 2003; 289:2230-2237. PMid:12734134 http://dx.doi.org/10.1001/jama.289.17.2230

[3] Johns MW. Daytime sleepiness, snoring, and obstructive sleep apnea: the Epworth Sleepiness Scale. Chest 1993;103:30-36. PMid:8417909 http://dx.doi.org/10.1378/chest.103.1.30

[4] Gottlieb DJ, Whitney CW, Bonekat WH, Iber C, James GD, Lebowitz M, Nieto FJ, Rosenberg CE. Relation of sleepiness to respiratory disturbance index: the Sleep Heart Health Study. Am J Respir Crit Care Med.1999;159:502-507. PMid:9927364

[5] Park JG, Ramar K, Olson EJ. Updates on definition, consequences, and management of obstructive sleep apnea. Mayo Clin Proc 2011; 86:549-554. PMid:21628617 http://dx.doi.org/10.4065/mcp.2010.0810

[6] Young T, Peppard PE, Taheri S. Excess weight and sleep-disordered breathing. J Appl Physiol. 2005; 99:1592-1599. PMid:16160020 http://dx.doi.org/10.1152/japplphysiol.00587.2005

[7] Lopez PP, Stefan B, Schulman CI, Byers PM. Prevalence of sleep apnea in morbidly obese patients who presented for weight loss surgery evaluation: more evidence for routine screening for obstructive sleep apnea before weight loss surgery. Am Surg 2008; 74:834-838. PMid:18807673 
[8] Schwartz AR, Patil SP, Laffan AM, Polotsky V, Schneider H, Smith PL. Obesity and obstructive sleep apnea: pathogenic mechanisms and therapeutic approaches. Proc Am Thorac Soc. 2008; 5:185-192. PMid:18250211 http://dx.doi.org/10.1513/pats.200708-137MG

[9] Fritscher LG, Mottin CC, Canani S, Chatkin J. Obesity and obstructive sleep apnea-hypopnea syndrome: the impact of bariatric surgery. Obes Surg. 2007;17:95-99. PMid:17355775 http://dx.doi.org/10.1007/s11695-007-9012-7

[10] Greenstein AJ, Wahed AS, Adeniji A, Courcoulas AP, Dakin G, Flum DR, et al. Prevalence of adverse intraoperative events during obesity surgery and their sequelae. J Am Coll Surg. 2012;215:271-277. PMid:22634116 http://dx.doi.org/10.1016/j.jamcollsurg.2012.03.008

[11] Strommen M, Kulseng B, Vedul-Kjelsås E, Johnsen H, Johnsen G, Mårvik R. Bariatric surgery or lifestyle intervention? An exploratory study of severely obese patients’ motivation for two different treatment. Obes Res Clin Pract. 2009;3:193-201. http://dx.doi.org/10.1016/j.orcp.2009.04.004

[12] Tuomilehto HP, Seppa JM, Partinen MM, Peltonen M, Gylling H, Tuomilehto JO, et al. Lifestyle intervention with weight reduction: first-line treatment in mild obstructive sleep apnea. Am J Respir Crit Care Med. 2009;179:320-327. PMid:19011153 http://dx.doi.org/10.1164/rccm.200805-669OC

[13] Johansson K, Neovius M, Lagerros YT, Harlid R, Rössner S, Granath F, et al. Effect of a very low energy diet on moderate and severe obstructive sleep apnoea in obese men: a randomised controlled trial. BMJ. 2009;339:b4609. PMid:19959590 http://dx.doi.org/10.1136/bmj.b4609

[14] Tuomilehto H, Gylling H, Peltonen M, Martikainen T, Sahlman J, Kokkarinen J, et al. Sustained improvement in mild obstructive sleep apnea after a diet- and physical activity-based lifestyle intervention: postinterventional follow-up. Am J Clin Nutr. 2010; 92:688-699. PMid:20702607 http://dx.doi.org/10.3945/ajcn.2010.29485

[15] Johansson K, Hemmingsson E, Harlid R, Trolle Lagerros Y, Granath F, Rössner S, et al. Longer term effects of very low energy diet on obstructive sleep apnea in cohort derived from randomised controlled trial: prospective observational follow-up study. BMJ. 2011; 342:d3017. PMid:21632666 http://dx.doi.org/10.1136/bmj.d3017

[16] Barnes M, Goldsworthy UR, Cary BA, Hill CJ. A diet and exercise program to improve clinical outcomes in patients with obstructive sleep apnea-a feasibility study. J Clin Sleep Med. 2009; 5:409-415. PMid:19961023

[17] Sumithran P, Proietto J. Safe year-long use of a very-low-calorie diet for the treatment of severe obesity. Med J Aust. 2008;188:366-368. PMid:18341463

[18] Saris WH. Very-low-calorie diets and sustained weight loss. Obes Res. 2001; 9:295S-301S. PMid:11707557 http://dx.doi.org/10.1038/oby.2001.134

[19] Plourde G, Prud'homme D. Managing obesity in adults in primary care. CMAJ. 2012;184:1039-1044. PMid:22586330 http://dx.doi.org/10.1503/cmaj.111640

[20] Hwang D, Shakir N, Limann B, Sison C, Kalra S, Shulman L, et al. Association of sleep-disordered breathing with postoperative complications. Chest. 2008;133:1128-1134.

PMid:18339794 http://dx.doi.org/10.1378/chest.07-1488

[21] Liao P, Yegneswaran B, Vairavanathan S, Zilberman P, Chung F. Postoperative complications in patients with obstructive sleep apnea: a retrospective matched cohort study. Can J Anaesth. 2009;56:819-828. PMid:19774431 http://dx.doi.org/10.1007/s12630-009-9190-y

[22] Regel H, Rose W, Hahnel S, Krause A. Evaluation of psychological stress before general anesthesia. Psychiatr Neurol Med Psychol. 1985; 37:151-155.

[23] Martins C, Strommen M, Stavne OA, Nossum R, Mårvik R, Kulseng B. Bariatric surgery versus lifestyle interventions for morbid obesity-changes in body weight, risk factors and comorbidities at 1 year. Obes Surg. 2011; 21:841-849.

PMid:20379796 http://dx.doi.org/10.1007/s11695-010-0131-1

[24] Foster GD, Borradaile KE, Sanders MH, Millman R, Zammit G, Newman AB, et al. A randomised study on the effect of weight loss on obstructive sleep apnea among obese patients with type 2 diabetes: the Sleep AHEAD study. Arch Intern Med. 2009;169:1619-1626. PMid:19786682 http://dx.doi.org/10.1001/archinternmed.2009.266

[25] Jakicic JM. The effect of physical activity on body weight. Obesity. 2009;17:S34-S38. PMid:19927144 http://dx.doi.org/10.1038/oby.2009.386

[26] Peppard PE, Young T. Exercise and sleep-disordered breathing: an association independent of body habitus. Sleep. 2004; 27:480-484. PMid:15164902

[27] Norman JF, Von Essen SG, Fuchs RH, McElligott M. Exercise training effect on obstructive sleep apnea syndrome. Sleep Res Online. 2000; 3:121-129. PMid:11382910

[28] Sengul YS, Ozalevli S, Oztura I, Itil O, Baklan B. The effect of exercise on obstructive sleep apnea: a randomized and controlled trial. Sleep Breath. 2011;15:49-56. 
PMid:19898884 http://dx.doi.org/10.1007/s11325-009-0311-1

[29] Kline CE, Crowley EP, Ewing GB, Burch JB, Blair SN, Durstine JL, et al. The effect of exercise training on obstructive sleep apnea and sleep quality: a randomized controlled trial. Sleep. 2011; 34:1631-1640. PMid:22131599

[30] Kline CE, Ewing GB, Burch JB, Blair SN, Durstine JL, Davis JM, et al. Exercise training improves selected aspects of daytime functioning in overweight adults with obstructive sleep apnea. J Clin Sleep Med. 2012; 8:357-365. PMid:22893765

[31] Ackel-D’Elia C, da Silva AC, Silva RS, Truksinas E, Sousa BS, Tufik S, et al. Effects of exercise training associated with continuous positive airway pressure treatment in patients with obstructive sleep apnea syndrome. Sleep Breath. 2012;16:723-735. PMid:21805226 http://dx.doi.org/10.1007/s11325-011-0567-0 